\title{
Recruiting the Digital-Age Applicant: The Impact of Ophthalmology Residency Program Web Presence on Residency Recruitment
}

\author{
Mark Goerlitz-Jessen, MD ${ }^{1}$ Nicholas Behunin, MD $^{2}$ \\ ${ }^{1}$ Duke Eye Center, Duke University, Durham, North Carolina \\ ${ }^{2}$ Kellogg Eye Center, University of Michigan, Ann Arbor, Michigan \\ 3 Residency Program, Penn State Hershey Eye Center, \\ Hershey, Pennsylvania
}

\author{
Maria Montijo ${ }^{3}$ Michael Wilkinson, $\mathrm{MD}^{3}$
}

Journal of Academic Ophthalmology 2018;10:e32-e37.

\begin{abstract}
Address for correspondence Mark Goerlitz-Jessen, MD, Duke Eye Center, Duke University, 5114 Long Leaf Drive, Durham, NC 27712 (e-mail: mfgjessen@gmail.com).
\end{abstract}

\begin{abstract}
Keywords

- ophthalmology residency

- website

- social media

- web presence

- recruitment

- residency application

- residency match
\end{abstract}

Background The phenomenon of internet dependence has changed the way the rising generation seeks information. This mentality has caused medical students to turn to online resources as they seek information about potential residency training programs. Residency program web presence (PWP) is increasingly important, and may even impact recruitment efforts. Improvement of PWP could enhance programs' recruitment of ideal candidates.

Objectives The purpose of this study is to assess how ophthalmology residency PWP is impacting the residency recruitment process by understanding how it influences applicants' application and rank list choices as well as to identify the contributing factors.

Methods Applicants applying for ophthalmology residency training at Penn State University during the 2015-2016 and 2016-2017 application cycles were surveyed using Research Electronic Data Capture (REDCap). Surveys sought applicants' perspectives with respect to their experiences with PWP and how those experiences shaped their application and rank list decisions.

Results Of 860 applicants, 214 (24.9\%) responded, accounting for $17.4 \%(214 / 1,228)$ of all ophthalmology residency applicants during the respective cycles; $72.4 \%$ of respondents expressed PWP does impact where they apply, how they form their rank list, or both; $93.4 \%$ said websites are an important resource during the application process; $47.2 \%$ conveyed interest in programs utilizing social media tools; and $76.5 \%$ of respondents felt websites gave sufficient information less than $50 \%$ of the time.

Conclusion Ophthalmology PWP does impact resident recruitment. By enhancing program websites and adding social media tools, programs can improve recruitment efforts.
This is the age of incessant digital information. People of all age groups are continually increasing their use of internet and social media networks as technology reliance explodes. ${ }^{1,2}$ For upper-level medical students, this means increased dependence on residency program web presence (PWP), which includes program websites, social media applications, and other online tools, when gathering information about resi-

received

June 15, 2017

accepted after revision

January 24, 2018
DOI https://doi.org/ ISSN 2475-4757. 10.1055/s-0038-1636513. dency programs during the application process. ${ }^{3-5}$ In addition, recent studies suggest the use of social media tools, such as Twitter and Facebook, permeate medical student preferences for residency program information dissemination. 6,7

Though program websites may not be the most important factor in recruitment, they do impact applicants' decisions. ${ }^{8}$ Studies in various specialties have found that the information
Copyright $\odot 2018$ by Thieme Medical Publishers, Inc., 333 Seventh Avenue, New York, NY 10001, USA. Tel: +1(212) 584-4662.
License terms

(1) (1) $\Theta \circledast$ 
available on residency program websites varies greatly. ${ }^{9,10}$ Due to varying amounts of information and inconsistent user-friendliness, students have been disillusioned by the quality of online resources. ${ }^{6}$ Other studies have concluded that programs are underutilizing these tools to reach out to and inform prospective applicants. ${ }^{7,11,12}$

In ophthalmology, investigations have separately evaluated the existence and content of residency program websites, and factors important in recruitment of applicants. ${ }^{10,13}$ However, to our knowledge, no study has evaluated the role of PWP in resident recruitment. The purpose of this study is to begin to understand whether PWP is impacting the residency recruitment process by influencing where applicants apply and how they form rank lists and, if so, to identify contributing factors.

\section{Methods}

\section{Study Design}

Using Research Electronic Data Capture (REDCap), a mixed model, cross-sectional, anonymous response survey was sent, via email link, to medical students applying for ophthalmology residency near the conclusion of their residency interview/ match process. All surveyed applicants applied to the ophthalmology residency program at the Pennsylvania State University for consideration in the 2015-2016 or 2016-2017 cycles. Each group was queried during their respective application period, near rank list submission. Survey questions explored the impact PWP had on their application and match process, what factors had the most impact, obstacles they encountered, and where they sought information about programs. Skip logic was used to ensure that respondents only answered those items that pertained to related previous responses.

Five questions required participants to "rank" items. This survey applied the rank system convention that a lower value is superior to a higher value. Three questions required ranking of program factors that may impact recruitment. The factors considered were additional application requirements, benefits, call schedules, conference schedules, contact information of program, community outreach opportunities, curriculum, deadlines for application, $\mathrm{FAQ}$ (frequently asked questions), facility information, faculty information, fellowship match history, international opportunities, interview dates, location, outside activities (leisure), perceived reputation, program philosophy, recommendation by faculty or resident, resident reviews/comments, research opportunities, resources, rotation schedules, surgical numbers, statistics (average OKAP scores, etc.), VA information, and other. Applicants were asked to rank their "top 5" of these factors, as they pertained to each question.

Two questions had respondents consider the usefulness of various social media platforms (Facebook, Twitter, Doximity, Student Doctor Network [SDN], and other) and preference of additional resources used (word of mouth, faculty, online databases, program coordinator or direct, and residents). Participants ranked all items in these questions from most to least.

Approval of this study was obtained from the Pennsylvania State University Internal Review Board.

\section{Data Analysis}

Generally, responses were analyzed based on summary statistics and response percentages. However, when a ranking of options was requested, the total number of ranks, the mean rank, and a weighted rank were calculated. The weighted rank was used to lend credence to both the mean rank and total number of ranks when comparing each answer choice. Weighted ranks were calculated as follows:

$$
\begin{aligned}
& \text { Weight rank = mean rank } \times \text { [1-(total rank/total items } \\
& \text { ranked) } .
\end{aligned}
$$

A weighted rank with a lower value is calculated to be superior to a higher value. In the rank comparisons, only options that received at least $10 \%$ of the sample's vote were considered significant. This eliminated the risk that the formula poses of having an item that was rarely ranked from outweighing an item that received a significant number of responses.

An inductive thematic analysis was performed on applicants' comments with regard to poorly navigable and userfriendly websites by two of the authors (M.G-J., M.M.). ${ }^{14}$ Based on the results of this review, themes with assigned numeric codes were established and the authors reviewed responses individually to assign a theme to each response. The authors then discussed the coding to come to an agreement on thematic assignments.

\section{Results}

The response rate was $214 / 860$ (24.9\%). This accounts for $17.4 \%$ of the 1,228 total applicants who submitted rank lists for ophthalmology residency during the 2015-2016 and 2016-2017 application cycles. ${ }^{15}$

\section{Impact of Web Presence}

With regard to the influence of PWP, 106 (49.53\%) respondents noted it impacts only where they apply, 13 (6.07\%) responded it impacts only their rank list, and 36 (16.8\%) indicated it impacts both where they apply and how they rank a program. Fifty-nine (27.6\%) indicated that web presence does not influence where they apply or how they make their rank list.

Of respondents, 201 (93.4\%) expressed websites are an important resource during the application process. One hundred and three (48.1\%) noted social media as a helpful tool for programs and 101 (47.2\%) would like to see an increase in the use of social media tools for dissemination of program information. The order of preferred social media tools (from most to least useful for applicants) was SDN, Doximity, Facebook, Twitter, and "other" (-Table 1).

Supplemental resources used by respondents, in addition to websites and social media, to learn about programs were ranked, in order of use, as follows: word of mouth, faculty at their home institution, residents at their home institution, online databases (e.g., FREIDA), program coordinator of the program of interest, program director of the program of interest, and "other" (-Table $\mathbf{1}$ ). 
Table 1 Applicants' web tool preferences, in addition to websites

\begin{tabular}{|c|c|c|c|}
\hline & $\begin{array}{l}\text { Weighted } \\
\text { rank }\end{array}$ & $\begin{array}{l}\text { Mean } \\
\text { rank }\end{array}$ & $\begin{array}{l}\text { Total } \\
\text { ranks }\end{array}$ \\
\hline \multicolumn{4}{|c|}{ Most useful social media platforms for applicants } \\
\hline $\begin{array}{l}\text { Student Doctor } \\
\text { Network (SDN) }\end{array}$ & 0.60407 & 2.63679 & 212 \\
\hline Doximity & 0.63642 & 2.73460 & 211 \\
\hline Facebook & 0.70048 & 2.91866 & 209 \\
\hline Twitter & 0.79120 & 3.29665 & 209 \\
\hline Other $^{\mathrm{a}}$ & 2.44868 & 2.97959 & 49 \\
\hline \multicolumn{4}{|c|}{$\begin{array}{l}\text { Other resources utilized by applicants to learn about } \\
\text { residency programs }\end{array}$} \\
\hline Word of mouth & 0.83795 & 2.95431 & 197 \\
\hline $\begin{array}{l}\text { Faculty at your } \\
\text { institution }\end{array}$ & 0.85449 & 2.97449 & 196 \\
\hline $\begin{array}{l}\text { Residents at your } \\
\text { institution }\end{array}$ & 1.04556 & 3.26738 & 187 \\
\hline $\begin{array}{l}\text { Online databases } \\
\text { (e.g., FREIDA) }\end{array}$ & 1.18703 & 3.62703 & 185 \\
\hline $\begin{array}{l}\text { Program coordina- } \\
\text { tor of the program } \\
\text { of interest }\end{array}$ & 1.67326 & 4.38235 & 170 \\
\hline $\begin{array}{l}\text { Program director of } \\
\text { the program of } \\
\text { interest }\end{array}$ & 1.72062 & 4.54971 & 171 \\
\hline Other $^{\mathrm{b}}$ & 3.42139 & 4.35593 & 59 \\
\hline
\end{tabular}

${ }^{a}$ Written responses receiving more than one comment: Instagram (7), LinkedIn (6), matchapplicants.com (4), program website (4), Google (2), YouTube (2), SF match (2), and additional information via email (2). bWritten responses receiving more than one comment: SDN/online forums (20), faculty and residents at other institution (7), Doximity (2), program website (2), and Google (2).

\section{Quality of Program Web Presence}

When asked about user-friendliness and navigability of websites, 183 (85.5\%) respondents indicated sites met those characteristics only "sometimes"; 19 (8.9\%) said sites were "rarely" navigable and friendly; and 12 (5.6\%) responded sites were "always" navigable and friendly. Three themes emerged when text responses for "rarely" were examined: exhaustive and misleading searches (9), lack of updated and relevant content (8), and broken links (2) (-Table 2 ).

Seventy-one (33.2\%) respondents indicated websites gave adequate information more than $50 \%$ of the time, while 143 (76.8\%) respondents noted information to be adequate $50 \%$ or less of the time. One hundred and ninety-nine (93.0\%) felt there were insufficient resident reviews and comments in PWP.

\section{Important Factors in Recruitment}

The factors most likely to determine if respondents applied to a program were, in order, surgical numbers, location, perceived reputation, recommendation by faculty or resident, and fellowship match history (-Table $\mathbf{3}$ ).
Table 2 Reasons applicants find websites to be rarely user friendly and navigable

\begin{tabular}{|c|c|}
\hline Applicant's comment & Theme $^{a}$ \\
\hline Information is extremely vague & 3 \\
\hline $\begin{array}{l}\text { Information not up to date, links often don't } \\
\text { work, websites difficult to find }\end{array}$ & 2 \\
\hline $\begin{array}{l}\text { It is not easy to find the links l'm looking for } \\
\text { such as links to the curriculum. Sometimes the } \\
\text { links do not lead to pages l'm looking for. For } \\
\text { example, "education" is not always graduate } \\
\text { medical education, sometimes it means } \\
\text { patient education }\end{array}$ & 1 \\
\hline $\begin{array}{l}\text { Lack of information or information that is } \\
\text { cached in an odd or difficult-to-find location }\end{array}$ & 2 \\
\hline $\begin{array}{l}\text { Lengthy unnecessary information posted. We } \\
\text { need concise information about surgical } \\
\text { volume and fellowship placements }\end{array}$ & 2 \\
\hline $\begin{array}{l}\text { Most websites include generic infos with no } \\
\text { specifics about what are you looking for in a } \\
\text { candidate leaving vague impressions. Websites } \\
\text { should have specific useful criteria }\end{array}$ & 2 \\
\hline $\begin{array}{l}\text { Often there are many hidden trees to get to } \\
\text { relevant information. I find myself having to } \\
\text { click on every single permutation of links to } \\
\text { ensure that I find all the information I want }\end{array}$ & 2 \\
\hline Old, outdated info & 3 \\
\hline $\begin{array}{l}\text { Outdated information, advertisement lan- } \\
\text { guage rather than program facts/surgical } \\
\text { numbers, etc. }\end{array}$ & 3 \\
\hline Relevant information usually requires digging & 2 \\
\hline $\begin{array}{l}\text { Several steps to find "education" or "residency } \\
\text { program." Faculty profiles and program } \\
\text { descriptions outdated and highlight "nones- } \\
\text { sential" on website }\end{array}$ & 2 \\
\hline $\begin{array}{l}\text { Sometimes the links do not work or the } \\
\text { information seems outdated }\end{array}$ & 1 \\
\hline $\begin{array}{l}\text { They often reveal little about the faculty and } \\
\text { current residents }\end{array}$ & 3 \\
\hline They seem outdated & 3 \\
\hline $\begin{array}{l}\text { Because they do not have important universal } \\
\text { info such as surgical numbers, fellowship } \\
\text { matches, current resident info (med school) }\end{array}$ & 3 \\
\hline $\begin{array}{l}\text { Hard to find residency site versus regular } \\
\text { ophthalmology department site }\end{array}$ & 2 \\
\hline Hard to find things & 2 \\
\hline Not a lot of information available & 3 \\
\hline $\begin{array}{l}\text { Outdated content, generic information, no } \\
\text { real sense of the unique aspects of the } \\
\text { program }\end{array}$ & 3 \\
\hline
\end{tabular}

aThemes: 1-broken links, 2-exhaustive and misleading searches, 3-lack of updated relevant content.

Whether a respondent ranked a program was most heavily influenced, in order, by location, surgical numbers, perceived reputation, program philosophy, and resident reviews/comments ( - Table 4 ). 
Recruiting the Digital-Age Applicant Goerlitz-Jessen et al. e35

Table 3 Factors determining application submission

\begin{tabular}{|c|c|c|c|}
\hline & $\begin{array}{l}\text { Weighted } \\
\text { rank }\end{array}$ & $\begin{array}{l}\text { Mean } \\
\text { rank }\end{array}$ & $\begin{array}{l}\text { Total } \\
\text { ranks }^{\text {a }}\end{array}$ \\
\hline \multicolumn{4}{|c|}{$\begin{array}{l}\text { Factors most likely to determine whether an applicant } \\
\text { applies to a residency program }\end{array}$} \\
\hline Surgical numbers & 1.54805 & 2.85714 & 126 \\
\hline Location(s) & 1.57726 & 2.76271 & 118 \\
\hline Perceived reputation & 1.64423 & 2.64423 & 104 \\
\hline Other & 1.76727 & 1.80000 & 5 \\
\hline $\begin{array}{l}\text { Recommendation by } \\
\text { faculty or resident }\end{array}$ & 1.83089 & 2.67816 & 87 \\
\hline $\begin{array}{l}\text { Fellowship match } \\
\text { history }\end{array}$ & 1.99969 & 3.02151 & 93 \\
\hline $\begin{array}{l}\text { Additional require- } \\
\text { ments (stereo vision, } \\
\text { statement of interest, } \\
\text { etc.) }\end{array}$ & 2.09455 & 2.18182 & 11 \\
\hline Program philosophy & 2.14319 & 2.75410 & 61 \\
\hline $\begin{array}{l}\text { Deadlines for } \\
\text { application }\end{array}$ & 2.16000 & 2.20000 & 5 \\
\hline Curriculum & 2.18366 & 2.94366 & 71 \\
\hline $\begin{array}{l}\text { Contact information } \\
\text { of program }\end{array}$ & 2.21727 & 2.25000 & 4 \\
\hline Conference schedules & 2.55273 & 2.60000 & 5 \\
\hline Interview dates & 2.77152 & 2.83333 & 6 \\
\hline $\begin{array}{l}\text { Positions available per } \\
\text { year }\end{array}$ & 2.89943 & 3.28125 & 32 \\
\hline $\begin{array}{l}\text { Resources available to } \\
\text { residents }\end{array}$ & 2.90667 & 3.0303 & 33 \\
\hline $\begin{array}{l}\text { Research } \\
\text { opportunities }\end{array}$ & 2.90681 & 3.56863 & 51 \\
\hline Faculty information & 2.93333 & 2.33333 & 33 \\
\hline VA information & 2.96242 & 3.13333 & 15 \\
\hline Benefits & 3.00476 & 3.15385 & 13 \\
\hline Call schedules & 3.02295 & 3.37931 & 29 \\
\hline Rotation schedules & 3.04242 & 3.33333 & 24 \\
\hline $\begin{array}{l}\text { Community outreach } \\
\text { opportunities }\end{array}$ & 3.18623 & 3.35714 & 14 \\
\hline Facility information & 3.23750 & 3.43750 & 16 \\
\hline $\begin{array}{l}\text { Statistics (OKAP } \\
\text { scores, etc.) }\end{array}$ & 3.25403 & 3.42857 & 14 \\
\hline $\begin{array}{l}\text { International } \\
\text { opportunities }\end{array}$ & 3.42273 & 3.75000 & 24 \\
\hline FAQ & 3.64955 & 3.87500 & 16 \\
\hline $\begin{array}{l}\text { Outside activities } \\
\text { (leisure) }\end{array}$ & 3.84000 & 4.00000 & 11 \\
\hline
\end{tabular}

${ }^{a}$ Only responses with greater than $10 \%$ (21) response rate considered significant.

Respondents said the most difficult items to find online were resident reviews/comments, surgical numbers, call schedules, program philosophy, and fellowship match history (-Table 5).
Table 4 Factors that determine whether or not a program is ranked

\begin{tabular}{|c|c|c|c|}
\hline & $\begin{array}{l}\text { Weighted } \\
\text { rank }\end{array}$ & $\begin{array}{l}\text { Mean } \\
\text { rank }\end{array}$ & $\begin{array}{l}\text { Total } \\
\text { ranks }^{\mathrm{a}}\end{array}$ \\
\hline $\begin{array}{l}\text { Contact information } \\
\text { of the program }\end{array}$ & 0.99636 & 1.00000 & 1 \\
\hline Location & 1.57141 & 2.73504 & 117 \\
\hline Surgical numbers & 1.69908 & 2.95726 & 117 \\
\hline Perceived reputation & 1.79955 & 2.79592 & 98 \\
\hline Program philosophy & 1.80283 & 2.55556 & 81 \\
\hline Other & 1.80818 & 1.95000 & 20 \\
\hline $\begin{array}{l}\text { Resident reviews/ } \\
\text { comments }\end{array}$ & 1.92642 & 2.78824 & 85 \\
\hline Interview dates & 2.16000 & 2.20000 & 5 \\
\hline Curriculum & 2.19000 & 2.75000 & 56 \\
\hline $\begin{array}{l}\text { Fellowship match } \\
\text { history }\end{array}$ & 2.20388 & 3.25843 & 89 \\
\hline $\begin{array}{l}\text { Recommendation } \\
\text { by faculty or } \\
\text { resident }\end{array}$ & 2.38088 & 3.01724 & 58 \\
\hline $\begin{array}{l}\text { Resources available } \\
\text { to residents }\end{array}$ & 2.63081 & 3.05263 & 38 \\
\hline Faculty information & 2.63865 & 2.92593 & 27 \\
\hline $\begin{array}{l}\text { Outside activities } \\
\text { (leisure, etc.) }\end{array}$ & 2.71161 & 2.84615 & 13 \\
\hline $\begin{array}{l}\text { Research } \\
\text { opportunities }\end{array}$ & 2.88406 & 3.41860 & 43 \\
\hline $\begin{array}{l}\text { Positions available } \\
\text { per year }\end{array}$ & 3.02545 & 3.20000 & 15 \\
\hline Rotation schedules & 3.03529 & 3.23529 & 17 \\
\hline $\begin{array}{l}\text { Statistics (OKAP } \\
\text { scores, etc.) }\end{array}$ & 3.08848 & 3.26667 & 15 \\
\hline Facility information & 3.20208 & 3.28571 & 7 \\
\hline Benefits & 3.64091 & 3.75000 & 8 \\
\hline $\begin{array}{l}\text { International } \\
\text { opportunities }\end{array}$ & 3.64235 & 3.88235 & 17 \\
\hline VA information & 3.69545 & 3.75000 & 4 \\
\hline Call schedules & 3.70023 & 4.18750 & 32 \\
\hline $\begin{array}{l}\text { Community outreach } \\
\text { opportunities }\end{array}$ & 3.94182 & 4.00000 & 4 \\
\hline $\begin{array}{l}\text { Conference } \\
\text { schedules }\end{array}$ & 3.95636 & 4.00000 & 3 \\
\hline FAQ & 3.97091 & 4.00000 & 2 \\
\hline $\begin{array}{l}\text { Deadlines for } \\
\text { application }\end{array}$ & - & - & $\begin{array}{l}\text { Not } \\
\text { ranked }\end{array}$ \\
\hline $\begin{array}{l}\text { Additional require- } \\
\text { ments (stereo } \\
\text { vision, statement of } \\
\text { interest, etc.) }\end{array}$ & - & - & $\begin{array}{l}\text { Not } \\
\text { ranked }\end{array}$ \\
\hline
\end{tabular}

${ }^{\mathrm{a} O n l y}$ responses with greater than $10 \%$ (21) response rate considered significant. 
Table 5 Residency program information that is most difficult to find

\begin{tabular}{|c|c|c|c|}
\hline & $\begin{array}{l}\text { Weighted } \\
\text { rank }\end{array}$ & $\begin{array}{l}\text { Mean } \\
\text { rank }\end{array}$ & $\begin{array}{l}\text { Total } \\
\text { ranks }^{\text {a }}\end{array}$ \\
\hline $\begin{array}{l}\text { Resident reviews/ } \\
\text { comments }\end{array}$ & 1.18997 & 2.51724 & 145 \\
\hline Surgical numbers & 1.26956 & 2.45865 & 133 \\
\hline Other & 1.97091 & 2.00000 & 4 \\
\hline Call schedules & 1.97834 & 2.98925 & 93 \\
\hline $\begin{array}{l}\text { Program } \\
\text { philosophy }\end{array}$ & 2.22258 & 2.57895 & 38 \\
\hline $\begin{array}{l}\text { Fellowship match } \\
\text { history }\end{array}$ & 2.38990 & 3.30263 & 76 \\
\hline $\begin{array}{l}\text { Positions available } \\
\text { per year }\end{array}$ & 2.46364 & 2.50000 & 4 \\
\hline $\begin{array}{l}\text { Resources avail- } \\
\text { able to residents }\end{array}$ & 2.48763 & 3.19672 & 61 \\
\hline Interview dates & 2.52424 & 2.83333 & 30 \\
\hline Curriculum & 2.54988 & 2.78261 & 23 \\
\hline FAQ & 2.70773 & 2.87500 & 16 \\
\hline $\begin{array}{l}\text { International } \\
\text { opportunities }\end{array}$ & 2.72153 & 3.15789 & 38 \\
\hline $\begin{array}{l}\text { Outside activities } \\
\text { (leisure, etc.) }\end{array}$ & 2.72153 & 3.15789 & 38 \\
\hline $\begin{array}{l}\text { Facility } \\
\text { information }\end{array}$ & 2.73818 & 3.00000 & 24 \\
\hline $\begin{array}{l}\text { Community out- } \\
\text { reach } \\
\text { opportunities }\end{array}$ & 2.77727 & 3.25000 & 40 \\
\hline $\begin{array}{l}\text { Conference } \\
\text { schedules }\end{array}$ & 2.80364 & 3.00000 & 18 \\
\hline $\begin{array}{l}\text { Research } \\
\text { opportunities }\end{array}$ & 2.96000 & 3.36364 & 33 \\
\hline $\begin{array}{l}\text { Rotation } \\
\text { schedules }\end{array}$ & 2.96417 & 3.38235 & 34 \\
\hline VA information & 2.98814 & 3.26087 & 23 \\
\hline $\begin{array}{l}\text { Faculty } \\
\text { information }\end{array}$ & 3.07286 & 3.40741 & 27 \\
\hline Benefits & 3.12034 & 3.53125 & 32 \\
\hline $\begin{array}{l}\text { Contact informa- } \\
\text { tion of program }\end{array}$ & 3.27636 & 3.40000 & 10 \\
\hline $\begin{array}{l}\text { Additional } \\
\text { requirements } \\
\text { (stereo vision, } \\
\text { statement of } \\
\text { interest, etc.) }\end{array}$ & 3.31123 & 3.52941 & 17 \\
\hline Locations & 3.33818 & 3.40000 & 5 \\
\hline $\begin{array}{l}\text { Deadlines for } \\
\text { application }\end{array}$ & 4.12364 & 4.20000 & 5 \\
\hline $\begin{array}{l}\text { Statistics (average } \\
\text { board score, etc.) }\end{array}$ & - & - & $\begin{array}{l}\text { Not } \\
\text { ranked }\end{array}$ \\
\hline
\end{tabular}

${ }^{a}$ Only responses with greater than $10 \%$ (21) response rate considered significant.

\section{Discussion}

Our survey indicates that PWP does impact recruitment. A majority of respondents, 155 (72.4\%), expressed PWP impacted where they applied, how they formed their rank list, or both, which suggests applicants are relying heavily on web tools throughout the interview and match processes. Such a reliance on web tools by applicants is not surprising, as dependence on the internet resources is continually increasing. ${ }^{8}$ Similar trends with residency program websites have also been established in other specialty programs. ${ }^{3-5}$ Furthermore, there is considerable interest among applicants for social media use by programs, though it did not reach a majority in our sample (47.2\%). Interestingly, if programs decide to use social media, their presence in this arena appears to be more important than the particular tool employed, as evidenced by the relatively even distribution of responses between SDN, Doximity, Facebook, and Twitter. As ophthalmology programs move forward, they should recognize the impact their PWP has on recruitment efforts. Understanding applicants' preferences with respect to web tools will allow programs to better address the needs of prospective residents.

Unfortunately, ophthalmology applicants feel program websites are frequently difficult to use, with all respondents indicating websites are unfriendly and unnavigable to some degree. Notably, some information applicants indicate as being most impactful, such as resident reviews, program philosophy, fellowship match details, and surgical volume are also items that are among the most difficult to find. Such sentiments expressing gaps in PWP are consistent with what has been found in other specialties, indicating this may be a global issue. $8,11,12,16,17$ Nonetheless, the current state of ophthalmology PWP complicates applicants' decision making and hampers their ability to determine which programs are a good fit. By maintaining an up-to-date, easy-to-use, and navigable program website, including key information, and utilizing social media tools, programs may increase their appeal to prospective residents by better aligning their PWP with applicants' interests.

We recognize the challenges programs face in developing their PWP. Time and resource constraints, institutional guidelines, preferences with respect to the publicity of particular program details, and other factors all impact PWP. Nonetheless, any efforts made to advance PWP may improve recruitment efforts.

There are certainly other important elements considered by applicants in the recruitment process, including program location, program reputation, the interview experience, etc. Though these are not thoroughly considered here, the purpose of this data is to provide an initial understanding of the applicants' perspective of the evolving impact of PWP on recruitment. The data presented may serve as a starting point for programs as they hone their own online identity.

Limitations of this study include the response rate as well as the group surveyed, given all responses came from medical students who applied to one ophthalmology program. Though the total number of respondents encompasses approximately two-thirds of the general applicant pool, 
there may be subgroups that were not surveyed. Furthermore, surveys are subject to self-reporting biases and may not always reflect true behavior. This survey was administered during the application period, near rank list submission, to minimize recall bias. However, the timing of each individual's response when compared with their interviews, application and rank list decisions, may have played a role in their answer selections.

\section{Conclusion}

In conclusion, residency programs' online efforts do impact recruitment to some extent. Programs should continue to refine their use of online tools as they seek to enhance the process of attracting applicants who will fit well in their respective programs.

Conflict of Interest

None declared.

\section{IRB Approval}

The Pennsylvania State University Institutional Review Board approved this study.

\section{Presentation}

Oral presentation at 2016 Association of University Professors of Ophthalmology (AUPO), Program Coordinator's Annual Meeting, January 28, 2016, Ft. Lauderdale, Florida. Presenter: Mark Goerlitz-Jessen.

Supplementary Material

Applicant survey tool used in this study.

Acknowledgments

The authors thank Erik Lehman, MS, for providing statistical consultation.

\section{References}

1 Pew Research Center. Generations. Available at: http://www.pewinternet.org/2010/12/16/generations-2010/. Accessed September 10, 2015
2 Pew Research Center. Social Media Usage: 2005-2015. Available at: http://www.pewinternet.org/2015/10/08/social-networkingusage-2005-2015/. Accessed September 10, 2015

3 Brazin LR. Sources of information on postgraduate medical training programs - 2002 update. Med Ref Serv Q 2002;21(02):1-14

4 Delzell JE Jr, Weick R, Weick M. How do medical students gather information about residency training programs? Mo Med 2003; 100(02):153-154

5 Winters RC, Hendey GW. Do web sites catch residency applicants? Acad Emerg Med 1999;6(09):968-972

6 Deloney LA, Perrot LJ, Lensing SY, Jambhekar K. Radiology resident recruitment: A study of the impact of web-based information and interview day activities. Acad Radiol 2014;21(07): 931-937

7 Schweitzer J, Hannan A, Coren J. The role of social networking web sites in influencing residency decisions. J Am Osteopath Assoc 2012;112(10):673-679

8 Mahler SA, Wagner MJ, Church A, Sokolosky M, Cline DM. Importance of residency program web sites to emergency medicine applicants. J Emerg Med 2009;36(01):83-88

9 Kumar A, Sigal Y, Wilson E. Web sites and pediatric residency training programs in the United States. Clin Pediatr (Phila) 2008; 47(01):21-24

10 Mayo GL, Lindhorst GC, Rosende C. American ophthalmology graduate medical education and the web: current state of internet resource utilization. Am J Ophthalmol 2003;135(05):708-709

11 Ashack KA, Burton KA, Soh JM, et al. Evaluating dermatology residency program websites. Dermatol Online J 2016;22(03): pii:13030/qt7rx3j2dn

12 Reilly EF, Leibrandt TJ, Zonno AJ, Simpson MC, Morris JB. General surgery residency program websites: usefulness and usability for resident applicants. Curr Surg 2004;61(02):236-240

13 Yousuf SJ, Kwagyan J, Jones LS. Applicants' choice of an ophthalmology residency program. Ophthalmology 2013;120(02): 423-427

14 Ebrahim S, Bowling A. Handbook of Health Research Methods: Investigation, Measurement and Analysis. New York, NY: McGrawHill International; 2005

15 San Francisco Match, Residency and Fellowship Matching Services. 2016 and 2017 Statistics. Available at: https://www.sfmatch.org/ SpecialtyInsideAll.aspx $? \mathrm{id}=6 \& \mathrm{typ}=2 \&$ name $=0$ phthalmology\# . Accessed February 2, 2017

16 Silvestre J, Tomlinson-Hansen S, Fosnot J, Taylor JA. Plastic surgery residency websites: a critical analysis of accessibility and content. Ann Plast Surg 2014;72(03):265-269

17 Embi PJ, Desai S, Cooney TG. Use and utility of Web-based residency program information: a survey of residency applicants. J Med Internet Res 2003;5(03):e22 